\title{
Sensory Characteristics and Related Volatile Flavor Compound Profiles of Different Types of Whey
}

\author{
F. J. Gallardo-Escamilla, ${ }^{1}$ A. L. Kelly, ${ }^{1}$ and C. M. Delahunty ${ }^{2}$ \\ ${ }^{1}$ Department of Food and Nutritional Sciences, University College Cork, Cork, Ireland \\ ${ }^{2}$ Sensory Science Research Centre, Department of Food Science, University of Otago, \\ Dunedin, New Zealand
}

\section{ABSTRACT}

To characterize the flavor of liquid whey, 11 samples of whey representing a wide range of types were sourced from cheese and casein-making procedures, either industrial or from pilot-plant facilities. Whey samples were assessed for flavor by descriptive sensory evaluation and analyzed for headspace volatile composition by proton transfer reaction-mass spectrometry (PTRMS). The sensory data clearly distinguished between the samples in relation to the processes of manufacture; that is, significant differences were apparent between cheese, rennet, and acid wheys. For Mozzarella and Quarg wheys, in which fermentation progressed to low $\mathrm{pH}$ values, the starter cultures used for cheese making had a significant influence on flavor. In comparison, Cheddar and Gouda wheys were described by milklike flavors, and rennet casein wheys were described by "sweet" (oat-like and "sweet") and thermally induced flavors. The volatile compound data obtained by PTRMS differentiated the samples as distinctive and reproducible "chemical fingerprints". On applying partial least squares regression to determine relationships between sensory and volatile composition data, sensory characteristics such as "rancid" and cheese-like odors and "caramelized milk," yogurt-like, "sweet," and oatlike flavors were found to be related to the presence and absence of specific volatile compounds.

(Key words: whey, flavor, sensory analysis, headspace volatile analysis)

Abbreviation key: $\mathbf{P C}=$ principal components, $\mathbf{P C A}=$ principal component analysis, $\mathbf{P L S R}=$ partial least squares regression, PTR-MS = proton transfer reaction-mass spectrometry.

\section{INTRODUCTION}

The dairy industry produces several types of whey as by-products of cheese making or casein production:

Received February 28, 2005

Accepted April 7, 2005.

Corresponding author: Alan L. Kelly; e-mail: a.kelly@ucc.ie. (a) "sweet" whey ( $\mathrm{pH} \geq 5.8$ ), which can be obtained either from the manufacture of natural enzyme-produced cheeses (e.g., Cheddar, Edam), i.e., cheese whey, or from the production of (rennet) caseinates, i.e., rennet casein whey; (b) medium acid whey (pH 5.0 to 5.8), from the manufacture of some fresh acid cheeses (e.g., Danbo, queso blanco); (c) acid whey $(\mathrm{pH}<5.0)$ obtained from the manufacture of fresh acid cheeses (e.g., Quarg, cottage, cream-Neufchâtel); and (d) acid casein whey, obtained from the production of acid casein by acidification of skimmed milk (Kosikowski and Mistry, 1997; Zadow, 2003).

Many whey utilization strategies involve fractionation and recovery of valuable constituents, such as proteins and lactose, for further processing or production of dry ingredients such as whey protein concentrates. However, a problem with such approaches is the low total solids content (approximately 6\%, wt/wt) of whey, which reduces the efficiency of processing (Ryder, 1980; Mehrens, 2004).

Another option for whey use takes advantage of its high water content to produce beverages. Fresh liquid whey, however, is associated with high transportation costs and susceptibility to deterioration during storage (Jensen and Kroger, 2000) and also with unappealing sensory characteristics (Jelen, 1992).

It is known that different cheese and casein-making procedures result in different chemical compositions of whey (Durham et al., 1997; Ji and Haque, 2003). Further differences in composition arise from activities of coagulants (Reineccius, 1994) and starter cultures (Romero, 1992) during the initial steps of cheese making, but little is known about source-related variations in the flavor and volatile composition of liquid whey.

Although most research on whey has been devoted to the improvement of processing methods, few studies have analyzed the impact of source and processing of whey on perceived flavor. In such studies, sensory evaluation, when performed, has been applied to determine which components are responsible for undesirable flavors, particularly when whey is used as a dry ingredient added to a product (e.g., Livney and Bradley, 1994) rather than to describe flavor. The majority of reports 
Table 1. Origin of whey samples.

\begin{tabular}{|c|c|c|c|}
\hline Origin & Source & Type of whey & Casein coagulation \\
\hline \multicolumn{4}{|l|}{ Cheese making } \\
\hline Cheddar cheese & Company A & "Sweet", Cheese & Unknown starter \\
\hline Cheddar cheese & Company B & "Sweet", Cheese & Unknown starter \\
\hline Cheddar cheese & Pilot plant & "Sweet", Cheese & Commercial starter R- $604^{1}$ \\
\hline Gouda cheese & Pilot plant & "Sweet", Cheese & Commercial starter B- $11^{1}$ \\
\hline Mozzarella cheese & Pilot plant & "Sweet", Cheese & Commercial starter TCC- $3^{1}$ \\
\hline Paneer cheese & Pilot plant & Medium acid & Citric acid solution, $1 \% \mathrm{wt} / \mathrm{wt}$ \\
\hline Quarg (fresh cheese) & Pilot plant & Acid & Commercial starter XT-202 ${ }^{1}$ \\
\hline \multicolumn{4}{|l|}{ Casein production } \\
\hline Rennet casein & Company A & "Sweet", Rennet casein & Unknown rennet \\
\hline Rennet casein & Pilot plant & "Sweet", Rennet casein & Commercial rennet Std. Plus $190^{1}$ \\
\hline Acid casein & Company A & Acid casein & Unknown acid \\
\hline Lactic acid casein & Pilot plant & Acid casein & Lactic acid solution, ${ }^{1} 10 \% \mathrm{vol} / \mathrm{vol}$ \\
\hline
\end{tabular}

${ }^{1}$ Starter cultures: $\mathrm{R}-604$ = Lactococcus lactis $\mathrm{spp}$. cremoris, Lactococcus lactis $\mathrm{spp}$. lactis; $\mathrm{B}-11$ = Lactococcus lactis spp. cremoris, Lactococcus lactis spp. lactis, Leuconostoc mesenteroides spp. cremoris, Lactococcus lactis spp. diacetylactis; TCC-3 = Streptococcus thermophilus, Lactobacillus delbrueckii spp. bulgaricus; XT202 = Lactococcus lactis spp. cremoris, Leuconostoc pseudomesenteroides, Lactococcus lactis spp. lactis biovar. diacetylactis. All starters, rennet (Std. Plus 190), and lactic acid (food-grade) were provided by Chr. Hansen Ltd., Ireland.

on flavor of whey have focused on the flavor chemistry of whey protein concentrates (e.g., Morr and Ha, 1991; Mills, 1993; Laye et al., 1995).

Some confusion about flavor of whey exists in the literature, because it is not always clear if it refers to whey in dry form, as an ingredient in a formula, reconstituted, or liquid (raw). Information on the flavor of liquid whey is scarce, with a single report on flavor of acid whey (McGugan et al., 1979), and a small number on a single type of cheese (Cheddar) whey (Carunchia Whetstine et al., 2003; Karagul-Yuceer et al., 2003; Tomaino et al., 2004).

Knowledge and understanding of how the flavor of liquid whey is affected by technological variables is important, because it may help (a) to develop products such as carbonated beverages, whey-based fruit drinks, dairy type (fermented and unfermented) products, and alcoholic beverages, (b) to understand the nature of chemical reactions detrimental to the flavor of whey, and (c) to allow control of the shelf life of such products. Research on sensory evaluation of liquid whey is also necessary to improve the flavor of dried whey.

The objectives of this study were: 1) to characterize the flavor of liquid whey representing a range of cheese making and casein production procedures, 2) to assess the potential of different types of whey for specific applications due to their sensory profiles, 3) to examine, using a rapid method of headspace analysis, the flavor significance of the volatile composition for that range of samples, and 4) to establish relationships between sensory characteristics and volatile composition to enable more efficient control of whey flavor.

\section{MATERIALS AND METHODS}

\section{Samples}

Eleven samples of whey from a wide range of sources were analyzed. These represented each of the main types of whey, namely: cheese whey (from Cheddar, Gouda, and Mozzarella cheese-making), rennet casein whey (made by addition of rennet to skim milk), medium acid whey (from Paneer, a soft heat- and acidcoagulated Indian cheese), and acid whey (derived from Quarg cheese making, or acid casein making). Details about the samples, provided by industrial cheese manufacturers (companies A and B) or produced in pilotplant cheese-making facilities, are given in Table 1.

Whey samples (4.5 L of each type) collected from pilotscale cheese-making trials were filtered through a cheese sieve to remove curd (casein) fines, centrifuged at $3500 \times g$ for $25 \mathrm{~min}$ at $6^{\circ} \mathrm{C}$ and filtered through Whatman No. 113 filter paper to remove fat (final fat content $<0.5 \%$ ). Samples from industrial manufacturers did not require filtration for curd fines but were skimmed by centrifugation and filtered under the same conditions.

Refrigerated samples from industrial cheese manufacturers were transported to the laboratory at $\sim 6^{\circ} \mathrm{C}$ and subsequently frozen at $-20^{\circ} \mathrm{C}$ until required. Pilotplant samples, after being cooled from temperatures ranging from 43 to $32^{\circ} \mathrm{C}$ depending on specific protocols, were also frozen at $-20^{\circ} \mathrm{C}$ until required.

Before analysis, samples were thawed at $6^{\circ} \mathrm{C}$ overnight; once thawed, samples were kept refrigerated (maximum $48 \mathrm{~h}$ ) at 4 to $6^{\circ} \mathrm{C}$ until $1.5 \mathrm{~h}$ before sensory 
evaluation or volatile headspace analysis, when they were allowed to reach room temperature $\left(\sim 20^{\circ} \mathrm{C}\right)$.

\section{Compositional Analysis}

Fat and protein content and total solids of samples were determined using a Milkoscan FT120 (FOSS Ireland, Dublin, Ireland). Whey $\mathrm{pH}$ was determined using a digital pH meter MP120 Mettler-Toledo (Schwerzenbach, Switzerland).

\section{Sensory Evaluation}

A panel of 10 assessors, with at least 2 yr of previous experience in descriptive sensory analysis of dairy products, was trained for sensory evaluation of the samples (Standard 8586; ISO, 1993). After discussion of terms in three 2-h sessions, a list of descriptors was defined (see list in Results and Discussion section). Panel homogeneous understanding of terms was verified by ANOVA and Kendall's coefficient of concordance of trial data (McDonnell et al., 2001). For evaluation, a 30-mL sample of each type of whey, in a 3-digit-coded glass, was presented to assessors in individual booths under controlled conditions of lighting and environment (Standard 8589; ISO, 1988) in a balanced order design (MacFie et al., 1989). Samples were assessed in duplicate on 2 separate days. On each day, 3 sessions, with a maximum of 4 samples per session were carried out. Samples were rated using $100-\mathrm{mm}$ unstructured line scales. Unsalted crackers and water were given to assessors for palate cleansing between each sample, and 15-min breaks between sessions were allowed to avoid sensory fatigue. Data was collected using Compusense Five, version 4.0 (Compusense Inc., Guelph, Ontario, Canada).

\section{Volatile Headspace Analysis by Proton Transfer Reaction-Mass Spectrometry}

A nonexhaustive but reliable, sensitive, and rapid analytical procedure, proton transfer reaction-mass spectrometry (PTR-MS), was used to characterize the volatile compounds in whey samples.

Proton transfer reaction-mass spectrometry is a mass spectrometric technique based on a particular implementation of chemical ionization using proton transfer from hydronium ions $\left(\mathrm{H}_{3} \mathrm{O}^{+}\right)$to the volatile compounds to be detected (Lindinger et al., 1998). This technique has been described in several papers (Hansel et al., 1995; Buhr et al., 2002) and has been successfully used for food analysis, especially for the determination of flavor volatiles (Boscaini et al., 2003; Mayr et al., 2003; Pollien et al., 2003).
Mass spectra for each sample were obtained using an Ionicon Analytic (Innsbruck, Austria) PTR-MS system. The analytical procedure involved placing each sample of whey $(50 \mathrm{~mL})$ in a $500-\mathrm{mL}$ glass flask. After standing for $1 \mathrm{~h}$ at room temperature $\left(\sim 20^{\circ} \mathrm{C}\right)$ to reach headspace equilibrium, the inlet of the PTR-MS was then connected by a polyethylene tube to the flask and the headspace sample was drawn by a vacuum pump at 20.8 $\mathrm{mL} / \mathrm{min}$. Masses were analyzed in a quadrupole mass spectrometer and detected as ion counts per second (cps) by a secondary electron multiplier (Balzers QMG421 and Balzers QC422, respectively, Balzers Instruments, Austria). The spectrometric data were collected over a range of mass to charge ratio $(\mathrm{m} / \mathrm{z}) 20$ to 170 atomic mass units (amu). Headspace samples were analyzed using a constant drift voltage of $600 \mathrm{~V}$; drift pressure was set at $1.998 \pm 0.005$ mbar. Analysis of samples was performed in duplicate on 2 consecutive days, collecting the data through a computer interface connected to the mass spectrometer using Balzers Quadstar 422 software (Balzers Instruments).

\section{Data Analysis}

Sensory and volatile headspace data were analyzed by 1-way ANOVA and subsequent (posthoc) Duncan's multiple range test using SPSS for Windows version 11.0.1 (SPSS Inc., Chicago, IL). Principal components analysis (PCA) on each set of data, cross validated, and standardized (1/standard deviation), was performed using Unscrambler version 9.1.2 (CAMO Process AS, Oslo, Norway). An ANOVA was also carried out on PCA scores generated from the duplicate sensory ratings to determine the significance of principal components (PC). Partial least squares regression (PLSR) Types 1 and 2 (single and multiple response, respectively) (Martens and Martens, 1986) were carried out using Unscrambler version 9.1.2 for modeling relationships between chemical compounds and sensory characteristics.

Partial least squares regression is a multivariate regression method for relating the variations in one or several response variables ( $\mathrm{Y}$ variables, in this study the sensory attributes) to the variations of several predictors (X variables, chemical compounds), with explanatory or predictive purposes. Although PSR Type 1 models a single $\mathrm{Y}$ variable, PLSR Type 2 models multiple $\mathrm{Y}$ variables simultaneously and is useful when there is collinearity between $\mathrm{Y}$ variables.

\section{RESULTS AND DISCUSSION}

\section{Compositional Analysis}

Compositional data of samples analyzed (Table 2) were consistent with those reported by Kosikowski and 
Table 2. Gross composition and $\mathrm{pH}$ of wheys.

\begin{tabular}{lllll}
\hline & \multicolumn{4}{c}{ Composition } \\
\cline { 2 - 5 } & $\begin{array}{l}\text { Total } \\
\text { solids, }\end{array}$ & $\begin{array}{l}\text { Protein, } \\
\%\end{array}$ & $\begin{array}{l}\text { Fat, } \\
\%\end{array}$ & $\mathrm{pH}$ \\
\hline Whey sample & $\%$ & 0.91 & 0.47 & 6.31 \\
\hline Cheddar, company A & 7.1 & 0.68 & 0.39 & 6.10 \\
Cheddar, company B & 6.4 & 0.78 & 0.38 & 5.81 \\
Cheddar, pilot plant & 6.5 & 0.82 & 0.49 & 6.27 \\
Gouda & 6.5 & 0.85 & 0.29 & 4.61 \\
Mozzarella & 6.1 & 0.70 & 0.18 & 5.52 \\
Paneer & 5.7 & 0.76 & 0.14 & 4.36 \\
Quarg & 6.3 & 0.82 & 0.09 & 6.58 \\
Rennet casein, company A & 6.1 & 0.84 & 0.12 & 6.68 \\
Rennet casein, pilot plant & 6.1 & 0.70 & 0.10 & 4.48 \\
Acid casein, company A & 5.9 & 0.68 & 0.10 & 4.61 \\
Lactic acid casein & 6.9 & & & \\
\hline
\end{tabular}

Mistry (1997), except for Mozzarella whey. A possible explanation for its low $\mathrm{pH}$ could be that before being frozen, this sample was cooled more slowly than the other samples (as the temperature gradient was the widest) allowing further fermentation by the fast-acidification commercial starter culture used.

Processing parameters known to affect composition of whey include pasteurization of cheese milk, type and amount of bacterial starter cultures, type and concentration of coagulant used, treatment of the cheese curd before whey drainage, and removal of residual lipids from the whey (Olling and van Luin, 1988; Johansen et al., 2002).

\section{Sensory Characteristics of Whey Samples}

Karagul-Yuceer et al. (2003) reported that the flavor of whey depends on the variety of cheese produced, and Carunchia Whetstine et al. (2003) assumed that wheys made from different types of cheese have different flavor, but this was not ascertained because their results were based on observations on only one type of cheese (Cheddar) whey. These assumptions were probably based on findings by Bodyfelt et al. (1988) with reference to the flavor of whey powder, which can be produced from whey derived from production of different types of cheese.

In this study, all the sensory characteristics used in the descriptive analysis, except "caramelized" odor, significantly discriminated between the whey samples (Table 3).

The term "cheesy," discussed across all samples during the training sessions and assessed during evaluation, although discriminating in intensity, could not be attributed specifically to whey from a particular type of cheese. This was consistent with the fact that flavor is not developed in cheese until the ripening stage (Reineccius, 1994) and with the proposition that all fresh cheeses have a "common basic cheese taste" (Urbach, 1995). Results suggested that differences in flavor of whey basically refer to different intensities of attributes such as "acid," "sweet," "milky," and a (nonspecific) "cheesy" odor and, depending on processing and handling, notes indicating thermal, enzymatic, or microbiological effects.

The influence of the starter culture on flavor may be enhanced if it is not inactivated, as probably occurred for Mozzarella and Quarg cheese whey samples, which had significantly higher scores for yogurt odor and flavor than the rest of the samples. The starter cultures used for the manufacture of these 2 types of cheese, if active, produce ethanal (acetaldehyde) and 2,3 butadione (diacetyl) albeit by different biochemical pathways (Coolbear et al., 2003; Liu and Holland, 2003). Acetaldehyde and diacetyl are chemical compounds that impart characteristic yogurt aroma and flavor (Tamime and Robinson, 1999).

One of the strains of the starter culture used for manufacturing Gouda cheese (Lactococcus lactis spp. diacetylactis) also produces diacetyl and an acetaldehyde-thiamine complex (Ward et al., 2003) but the corresponding whey was not acid ( $\mathrm{pH}$ was 6.27 ). On the contrary, a yogurt flavor note was reported for the lactic acid casein sample, which had no starter culture added (a score higher than the average for this characteristic). These results suggest that an acid taste-odor interaction was involved in the perception of yogurt flavor.

The lack of any characteristic flavor note in Paneer whey may be a consequence of its nonrennet/nonstarter method of manufacture.

The scores for "dirty" odor were significantly higher in industrial Cheddar (from company A) and acid casein whey than the rest of the samples; this characteristic could originate from microbial growth for industrial Cheddar (A) or, in the case of acid casein wheys due to oxidation reactions (Bodyfelt et al., 1988; Tomaino et al., 2004).

McGugan et al. (1979) reported that undesirable flavors commonly recognized in acid whey include "salty," "bitter," "astringent/chalky," "nonvolatile acidity," and "volatile acidity." Similar sensory notes were perceived for the acid wheys in this study; however, there was a clear distinction between the whey samples from directly acidified milk and wheys (from lactic acid casein and industrial acid casein), and those resulting from fermentation (Quarg). Acid casein wheys obtained from direct acidification showed the highest sensory scores for off-odors such as "stale" and "rancid" (for industrial acid casein) and "dirty" (for lactic acid casein).

Nonvolatile compounds may have contributed significantly to explaining flavor variation, especially in differentiation of sweet and acid whey. These com- 
Table 3. Sensory scores ${ }^{1}$ (means) of samples analyzed and results of ANOVA.

\begin{tabular}{|c|c|c|c|c|c|c|c|c|c|c|c|c|c|}
\hline \multirow[b]{2}{*}{ Attribute } & \multicolumn{11}{|c|}{ Whey sample ${ }^{2}$} & \multirow[b]{2}{*}{$F$ value } & \multirow[b]{2}{*}{$P$ value } \\
\hline & ACASI & CHEDA & CHEDB & CHEDP & GOUDA & LACAS & MOZZ & PAN & QUARG & RCASA & RCASP & & \\
\hline \multicolumn{14}{|l|}{ Odor attributes } \\
\hline Pungent & $21^{\mathrm{ab}}$ & $19^{\mathrm{b}}$ & $5^{\mathrm{d}}$ & $8^{\mathrm{cd}}$ & $6^{\mathrm{d}}$ & $25^{\mathrm{a}}$ & $14^{\mathrm{bc}}$ & $13^{\mathrm{bc}}$ & $21^{\mathrm{ab}}$ & $9^{c}$ & $10^{\mathrm{c}}$ & 8.4 & 0.001 \\
\hline Sulfurous & $7^{\mathrm{b}}$ & $3^{\text {cd }}$ & $2^{\mathrm{cd}}$ & $5^{\mathrm{c}}$ & $3^{\mathrm{cd}}$ & $9^{b}$ & $10^{\mathrm{b}}$ & $4^{\mathrm{c}}$ & $15^{\mathrm{a}}$ & $2^{\text {cd }}$ & $3^{\text {cd }}$ & 16.0 & 0.000 \\
\hline Milky & $15^{\mathrm{c}}$ & $17^{\mathrm{c}}$ & $29^{\mathrm{a}}$ & $23^{\mathrm{ab}}$ & $26^{\mathrm{a}}$ & $8^{\mathrm{d}}$ & $21^{\mathrm{b}}$ & $24^{\mathrm{ab}}$ & $11^{\mathrm{d}}$ & $24^{\mathrm{ab}}$ & $22^{\mathrm{ab}}$ & 5.1 & 0.006 \\
\hline Rancid & $25^{\mathrm{ab}}$ & $20^{\mathrm{b}}$ & $8^{\mathrm{d}}$ & $11^{\text {cd }}$ & $9^{\text {cd }}$ & $32^{\mathrm{a}}$ & $15^{\mathrm{c}}$ & $13^{\mathrm{c}}$ & $19^{\mathrm{b}}$ & $13^{\mathrm{c}}$ & $12^{\mathrm{c}}$ & 4.5 & 0.010 \\
\hline Caramelized milk & 2 & 3 & 11 & 8 & 9 & 4 & 8 & 6 & 2 & 10 & 7 & 1.7 & 0.201 \\
\hline Natural yogurt & $4^{\mathrm{c}}$ & $0^{\mathrm{d}}$ & $5^{\mathrm{c}}$ & $11^{\mathrm{b}}$ & $6^{\mathrm{c}}$ & $5^{\mathrm{c}}$ & $30^{\mathrm{a}}$ & $6^{\mathrm{c}}$ & $26^{\mathrm{ab}}$ & $3^{\text {cd }}$ & $5^{\mathrm{c}}$ & 6.0 & 0.003 \\
\hline Oaty & $4^{\mathrm{d}}$ & $19^{\mathrm{ab}}$ & $19^{\mathrm{ab}}$ & $9^{c}$ & $16^{\mathrm{b}}$ & $5^{\mathrm{d}}$ & $3^{\mathrm{d}}$ & $12^{\mathrm{bc}}$ & $2^{\mathrm{d}}$ & $20^{\mathrm{ab}}$ & $14^{\mathrm{b}}$ & 5.9 & 0.003 \\
\hline Cheesy & $5^{b}$ & $5^{\mathrm{b}}$ & $4^{b}$ & $6^{\mathrm{b}}$ & $5^{b}$ & $6^{\mathrm{b}}$ & $16^{\mathrm{a}}$ & $6^{\mathrm{b}}$ & $17^{\mathrm{a}}$ & $1^{\mathrm{c}}$ & $7^{\mathrm{bc}}$ & 5.6 & 0.004 \\
\hline Heated/boiled milk & $18^{\mathrm{b}}$ & $27^{\mathrm{ab}}$ & $29^{\mathrm{a}}$ & $26^{\mathrm{ab}}$ & $33^{\mathrm{a}}$ & $6^{\mathrm{c}}$ & $17^{\mathrm{b}}$ & $28^{\mathrm{a}}$ & $4^{\mathrm{c}}$ & $31^{\mathrm{a}}$ & $28^{\mathrm{a}}$ & 4.3 & 0.012 \\
\hline Dirty & $37^{\mathrm{a}}$ & $32^{\mathrm{ab}}$ & $4^{\mathrm{d}}$ & $0^{\mathrm{d}}$ & $5^{\mathrm{d}}$ & $40^{\mathrm{a}}$ & $6^{\mathrm{d}}$ & $6^{\mathrm{d}}$ & $16^{\mathrm{c}}$ & $9^{d}$ & $8^{\mathrm{d}}$ & 24.9 & 0.000 \\
\hline Chemical & $15^{\mathrm{ab}}$ & $9^{b}$ & $1^{\mathrm{c}}$ & $1^{\mathrm{c}}$ & $1^{\mathrm{c}}$ & $24^{\mathrm{a}}$ & $2^{\mathrm{c}}$ & $5^{\mathrm{bc}}$ & $14^{\mathrm{ab}}$ & $7^{\mathrm{bc}}$ & $10^{\mathrm{b}}$ & 27.2 & 0.000 \\
\hline \multicolumn{14}{|l|}{ Flavor attributes } \\
\hline Heated/boiled milk & $27^{\mathrm{b}}$ & $39^{\mathrm{a}}$ & $41^{\mathrm{a}}$ & $36^{\mathrm{ab}}$ & $39^{\mathrm{a}}$ & $9^{\mathrm{d}}$ & $20^{\mathrm{c}}$ & $30^{\mathrm{b}}$ & $13^{\mathrm{d}}$ & $39^{\mathrm{a}}$ & $35^{\mathrm{ab}}$ & 15.9 & 0.000 \\
\hline Caramelized milk & $4^{\mathrm{d}}$ & $12^{\mathrm{b}}$ & $21^{\mathrm{a}}$ & $15^{\mathrm{b}}$ & $14^{\mathrm{b}}$ & $3^{\mathrm{d}}$ & $4^{\mathrm{d}}$ & $7^{\mathrm{cd}}$ & $3^{\mathrm{d}}$ & $12^{\mathrm{b}}$ & $6^{\mathrm{cd}}$ & 11.7 & 0.000 \\
\hline Acid & $36^{\mathrm{bc}}$ & $18^{\text {cd }}$ & $5^{\mathrm{d}}$ & $23^{\text {cd }}$ & $5^{\mathrm{d}}$ & $44^{\mathrm{a}}$ & $39^{b}$ & $18^{\mathrm{cd}}$ & $47^{\mathrm{a}}$ & $8^{\mathrm{d}}$ & $7^{\mathrm{d}}$ & 66.5 & 0.000 \\
\hline Sweet & $12^{\mathrm{de}}$ & $37^{\mathrm{ab}}$ & $37^{\mathrm{ab}}$ & $22^{\text {cd }}$ & $28^{\mathrm{c}}$ & $11^{\text {de }}$ & $8^{\mathrm{e}}$ & $21^{\mathrm{cd}}$ & $7^{\mathrm{e}}$ & $44^{\mathrm{a}}$ & $26^{\mathrm{c}}$ & 59.7 & 0.000 \\
\hline Bitter & $7^{\mathrm{bc}}$ & $5^{\mathrm{bc}}$ & $3^{\mathrm{c}}$ & $2^{\mathrm{c}}$ & $3^{\mathrm{c}}$ & $11^{\mathrm{ab}}$ & $14^{\mathrm{ab}}$ & $6^{\mathrm{bc}}$ & $18^{\mathrm{a}}$ & $2^{\mathrm{c}}$ & $4^{\mathrm{c}}$ & 11.2 & 0.000 \\
\hline Natural yogurt & $5^{\mathrm{d}}$ & $5^{\mathrm{d}}$ & $4^{\mathrm{d}}$ & $11^{\mathrm{c}}$ & $4^{\mathrm{d}}$ & $16^{\mathrm{b}}$ & $29^{\mathrm{a}}$ & $5^{\mathrm{d}}$ & $26^{\mathrm{a}}$ & $3^{\mathrm{d}}$ & $3^{\mathrm{d}}$ & 27.5 & 0.000 \\
\hline Stale & $22^{\mathrm{a}}$ & $22^{\mathrm{a}}$ & $9^{c}$ & $10^{\mathrm{c}}$ & $8^{\mathrm{c}}$ & $18^{\mathrm{ab}}$ & $9^{c}$ & $12^{\mathrm{bc}}$ & $15^{\mathrm{b}}$ & $18^{\mathrm{ab}}$ & $12^{\mathrm{bc}}$ & 3.2 & 0.035 \\
\hline Rancid & $38^{\mathrm{a}}$ & $31^{\mathrm{b}}$ & $16^{\mathrm{de}}$ & $5^{\mathrm{e}}$ & $6^{\mathrm{e}}$ & $32^{\mathrm{b}}$ & $24^{\mathrm{c}}$ & $12^{\mathrm{de}}$ & $28^{\mathrm{b}}$ & $8^{\mathrm{e}}$ & $8^{\mathrm{e}}$ & 14.6 & 0.000 \\
\hline Salty & $18^{\mathrm{a}}$ & $17^{\mathrm{a}}$ & $6^{\mathrm{c}}$ & $4^{\mathrm{c}}$ & $6^{\mathrm{c}}$ & $17^{\mathrm{a}}$ & $12^{\mathrm{b}}$ & $10^{\mathrm{bc}}$ & $9^{\mathrm{bc}}$ & $12^{\mathrm{b}}$ & $4^{\mathrm{c}}$ & 5.5 & 0.005 \\
\hline Oaty & $7^{\mathrm{c}}$ & $19^{\mathrm{a}}$ & $8^{\mathrm{c}}$ & $2^{\mathrm{d}}$ & $8^{c}$ & $2^{\mathrm{d}}$ & $1^{\mathrm{d}}$ & $4^{\mathrm{d}}$ & $2^{\mathrm{d}}$ & $16^{\mathrm{ab}}$ & $9^{c}$ & 33.0 & 0.000 \\
\hline Dirty & $35^{\mathrm{b}}$ & $24^{\mathrm{c}}$ & $2^{\mathrm{de}}$ & $3^{\text {de }}$ & $2^{\mathrm{de}}$ & $44^{\mathrm{a}}$ & $7^{\mathrm{d}}$ & $4^{\text {de }}$ & $5^{\text {de }}$ & $2^{\mathrm{de}}$ & $6^{\text {de }}$ & 41.1 & 0.000 \\
\hline \multicolumn{14}{|l|}{ Mouthfeel attributes } \\
\hline Mouth coating & $34^{\mathrm{b}}$ & $37^{\mathrm{a}}$ & $32^{\mathrm{b}}$ & $25^{\mathrm{bc}}$ & $26^{\mathrm{bc}}$ & $28^{\mathrm{bc}}$ & $22^{\mathrm{c}}$ & $26^{\mathrm{bc}}$ & $24^{\mathrm{c}}$ & $33^{\mathrm{b}}$ & $24^{\mathrm{c}}$ & 5.5 & 0.005 \\
\hline Chalky & $8^{\mathrm{bc}}$ & $7^{\mathrm{bc}}$ & $3^{\mathrm{c}}$ & $9^{b c}$ & $4^{\mathrm{c}}$ & $7^{\mathrm{bc}}$ & $9^{\mathrm{bc}}$ & $8^{\mathrm{bc}}$ & $18^{\mathrm{a}}$ & $3^{\mathrm{c}}$ & $8^{\mathrm{bc}}$ & 3.4 & 0.029 \\
\hline \multicolumn{14}{|c|}{ Residual flavor attributes } \\
\hline Metallic & $4^{\mathrm{c}}$ & $1^{\mathrm{c}}$ & $1^{\mathrm{c}}$ & $2^{\mathrm{c}}$ & $2^{\mathrm{c}}$ & $10^{\mathrm{ab}}$ & $12^{\mathrm{a}}$ & $4^{\mathrm{c}}$ & $13^{\mathrm{a}}$ & $1^{\mathrm{c}}$ & $2^{\mathrm{c}}$ & 9.4 & 0.000 \\
\hline Acid & $23^{\mathrm{bc}}$ & $14^{\mathrm{bc}}$ & $5^{\mathrm{c}}$ & $16^{\mathrm{bc}}$ & $5^{c}$ & $28^{\mathrm{b}}$ & $37^{\mathrm{a}}$ & $14^{\mathrm{bc}}$ & $40^{\mathrm{a}}$ & $5^{\mathrm{c}}$ & $6^{c}$ & 29.3 & 0.000 \\
\hline Bitter & $8^{\mathrm{bc}}$ & $5^{\mathrm{c}}$ & $3^{\mathrm{c}}$ & $2^{\mathrm{c}}$ & $3^{\mathrm{c}}$ & $11^{\mathrm{ab}}$ & $14^{\mathrm{a}}$ & $4^{\mathrm{c}}$ & $17^{\mathrm{a}}$ & $3^{\mathrm{c}}$ & $3^{\mathrm{c}}$ & 18.2 & 0.000 \\
\hline Astringent & $14^{\mathrm{ab}}$ & $10^{\mathrm{b}}$ & $3^{c}$ & $7^{\mathrm{bc}}$ & $4^{\mathrm{c}}$ & $15^{\mathrm{ab}}$ & $18^{\mathrm{a}}$ & $10^{\mathrm{b}}$ & $19^{\mathrm{a}}$ & $7^{\mathrm{bc}}$ & $4^{\mathrm{c}}$ & 10.0 & 0.000 \\
\hline Chemical & $6^{\mathrm{bc}}$ & $9^{b}$ & $2^{\mathrm{c}}$ & $4^{\mathrm{c}}$ & $1^{\mathrm{c}}$ & $22^{\mathrm{a}}$ & $6^{\mathrm{bc}}$ & $2^{\mathrm{c}}$ & $9^{b}$ & $2^{\mathrm{c}}$ & $2^{\mathrm{c}}$ & 18.3 & 0.000 \\
\hline Salty & $14^{\mathrm{ab}}$ & $13^{\mathrm{ab}}$ & $4^{\mathrm{c}}$ & $5^{\mathrm{bc}}$ & $3^{\mathrm{c}}$ & $17^{\mathrm{a}}$ & $12^{\mathrm{ab}}$ & $7^{b}$ & $8^{\mathrm{b}}$ & $7^{\mathrm{b}}$ & $3^{\mathrm{c}}$ & 10.0 & 0.000 \\
\hline Sweet & $14^{\mathrm{c}}$ & $28^{\mathrm{a}}$ & $23^{\mathrm{b}}$ & $13^{\text {cd }}$ & $20^{\mathrm{b}}$ & $8^{\text {cd }}$ & $3^{\mathrm{d}}$ & $16^{\mathrm{c}}$ & $2^{\mathrm{d}}$ & $32^{\mathrm{a}}$ & $13^{\mathrm{c}}$ & 29.1 & 0.000 \\
\hline
\end{tabular}

a,b,c,d,e After Duncan multiple range test, means within a row not sharing the same superscript were significantly different $(P<0.05)$.

${ }^{1}$ Sensory scores on 1-to-100 scale.

${ }^{2}$ Whey samples: ACASI = acid casein; CHEDA = Cheddar, company A; CHEDB = Cheddar, company B; CHEDP = Cheddar, pilot plant; GOUDA = Gouda cheese; LACAS = lactic acid casein; MOZZ = Mozzarella cheese; PAN = Paneer cheese; QUARG = Quarg cheese; RCASA = rennet casein, company A; RCASP = rennet casein, pilot plant. 


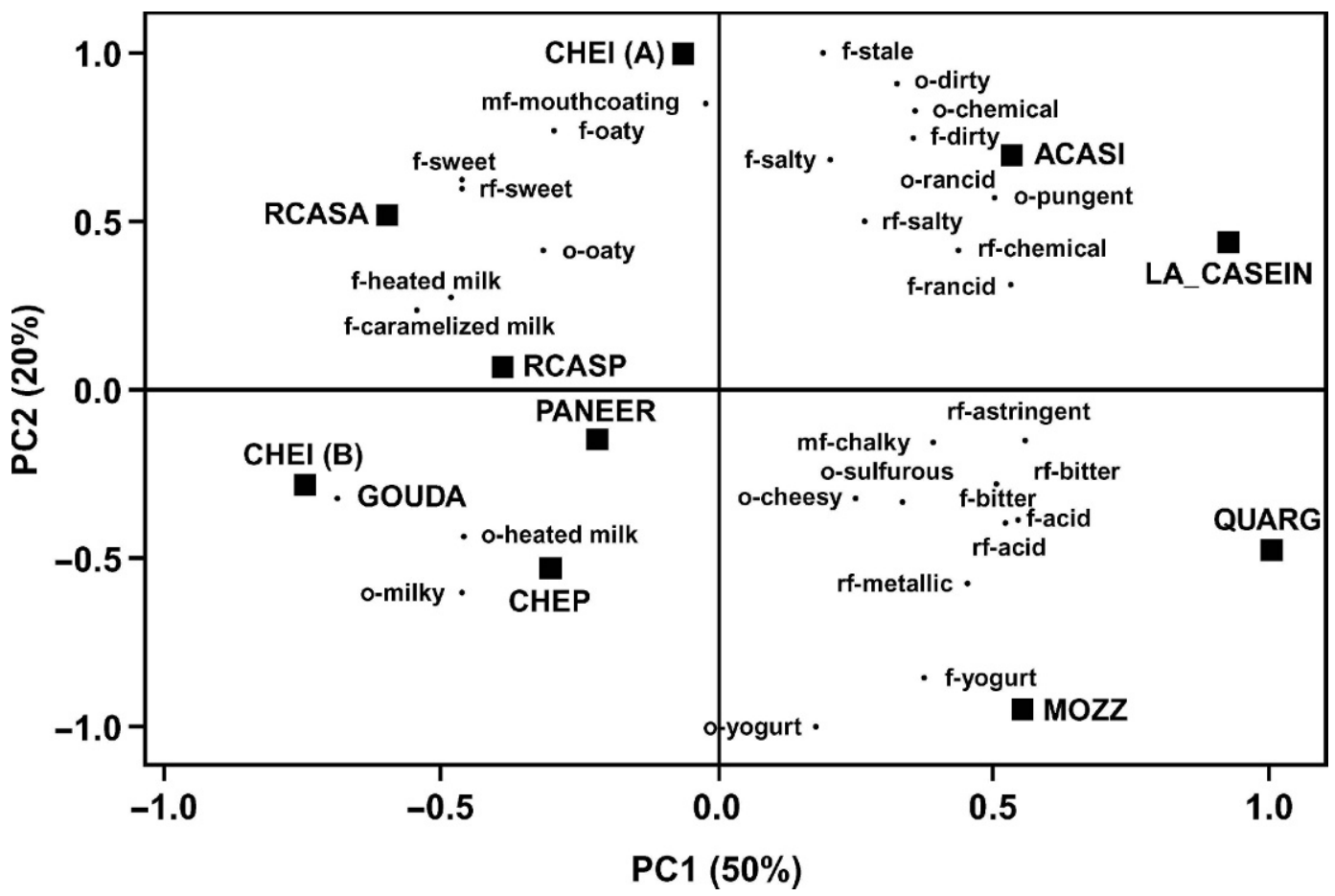

Figure 1. Results of principal component analysis of sensory attributes of wheys showing the first 2 principal components (PC1 and PC2). o- $^{-}$odor, $\mathrm{f}-$ = flavor, $\mathrm{mf}-$ = mouthfeel, $\mathrm{rf}-$ = residual flavor (after swallowing); yogurt = natural yogurt; heated milk = heated or boiled milk. Whey samples: ACASI = acid casein; CHEI(A) = Cheddar, company A; CHEI(B) = Cheddar, company B; CHEP = Cheddar, pilot plant; GOUDA = Gouda cheese; LA_CASEIN = lactic acid casein; MOZZ = Mozzarella cheese; PANEER = Paneer cheese; QUARG = Quarg cheese; RCASA = rennet casein, company A; RCASP = rennet casein, pilot plant.

pounds should therefore be considered and analyzed further as some of them may be relevant to the flavor of processed whey or whey beverages.

\section{PCA of Sensory Data}

The PCA diagram of sensory data (Figure 1) clearly illustrates differences between the samples and relationships between attributes on the first $2 \mathrm{PC}$, which accounted for $70 \%$ of explained variance. The ANOVA of PC scores, from means based on duplicate ratings (ANOVA not shown) found that the first 5 PC significantly discriminated $(P<0.05)$ between samples accounting for $93 \%$ (cumulative sum) of the total variance.

The PCA diagram showed that rennet and cheese wheys were differentiated from acid wheys. Component 1 , which explained $50 \%$ of the variance in the data set, showed that discrimination was mainly based on "acid," and "bitter" flavor and an "astringent" residual flavor (positive correlation to PC 1), and "heated or boiled milk" and "caramelized milk" flavors (negative correlation). Principal component 2 explained an additional $20 \%$ of the variance and was primarily a function of "natural yogurt" flavor (negative correlation to PC 2) and off-flavors such as "dirty" and "stale" (positive cor- relation). Loadings for "salty" (flavor and residual flavor) discriminated the acid wheys from the rest of the samples in an additional sensory dimension (PC 3).

\section{Headspace Volatile Compounds in Whey Samples}

Twenty-three volatile compounds detected by PTRMS significantly discriminated among samples (Table 4). Other compounds were detected in the samples but did not discriminate among them, and therefore were not included in subsequent analysis.

It was not possible to define key chemical compounds and concentrations that could be associated with a particular sample of whey. However, the PTR-MS spectra constituted a "chemical fingerprint" for each one of the samples; examples of the headspace volatile profiles of a sample with a fermented aroma, that is, a cheese (Mozzarella) whey and a less complex profile from lactic acid casein whey are shown in Figures 2 and 3.

Attribution of volatiles to the masses detected by PTR-MS in the samples was based on the molecular weight of compounds with a proton transferred (i.e., molecular weight +1 ), and cross-referenced to flavor studies in dairy products (Badings, 1991; Friedrich and Acree, 1998), processed whey (Mills, 1993; Rankin, 
Table 4. Average concentration (ppb) of significant volatile compounds detected by proton transfer reaction-mass spectrometry in the headspace of samples and results of ANOVA.

\begin{tabular}{|c|c|c|c|c|c|c|c|c|c|c|c|c|c|c|}
\hline \multirow[b]{2}{*}{$m / z^{2}$} & \multirow{2}{*}{$\begin{array}{l}\text { Volatile compound } \\
\text { attributed }^{3}\end{array}$} & \multicolumn{11}{|c|}{ Whey samples ${ }^{1}$} & \multirow[b]{2}{*}{$F$ value } & \multirow[b]{2}{*}{$P$ value } \\
\hline & & ACASI & CHEDA & CHEDB & CHEDP & GOUDA & LACAS & MOZZ & PAN & QUARG & RCASA & RCASP & & \\
\hline 41 & 1,2 propadiene; alkenyl (fr) & $3^{\mathrm{b}}$ & $12^{\mathrm{b}}$ & ND & $17^{\mathrm{b}}$ & $7^{b}$ & $14^{\mathrm{b}}$ & $7^{b}$ & $44^{\mathrm{a}}$ & $12^{\mathrm{b}}$ & $2^{\mathrm{b}}$ & $45^{\mathrm{a}}$ & 7.21 & 0.002 \\
\hline 42 & Allyl (r); dimethylamine & $4^{\mathrm{c}}$ & $8^{c}$ & $70^{\mathrm{a}}$ & $3^{\mathrm{c}}$ & $11^{\mathrm{c}}$ & $8^{\mathrm{c}}$ & $11^{\mathrm{c}}$ & $54^{\mathrm{b}}$ & $11^{\mathrm{c}}$ & $13^{\mathrm{c}}$ & $13^{\mathrm{c}}$ & 37.37 & 0.000 \\
\hline 43 & Propan-1-ol; alkyl (fr) & $34^{\mathrm{c}}$ & $255^{\mathrm{a}}$ & $55^{\mathrm{c}}$ & $23^{c}$ & $90^{c}$ & $177^{\mathrm{b}}$ & $88^{c}$ & $159^{\mathrm{b}}$ & $83^{\mathrm{c}}$ & $41^{\mathrm{c}}$ & $59^{c}$ & 13.18 & 0.000 \\
\hline 45 & Acetaldehyde & $11^{\mathrm{d}}$ & $107^{\mathrm{cd}}$ & $117^{\mathrm{cd}}$ & $3^{\mathrm{d}}$ & $462^{\mathrm{a}}$ & $18^{\mathrm{d}}$ & $786^{\mathrm{a}}$ & $209^{\mathrm{bc}}$ & $841^{\mathrm{a}}$ & $31^{\mathrm{d}}$ & $281^{\mathrm{b}}$ & 91.60 & 0.000 \\
\hline 46 & Hydrocarboxyl (r) & $3^{\text {cd }}$ & $4^{\mathrm{bcd}}$ & $4^{\text {bcd }}$ & $4^{\text {bcd }}$ & $21^{\mathrm{a}}$ & $12^{\mathrm{abc}}$ & $19^{\mathrm{a}}$ & $3^{\text {cd }}$ & $14^{\mathrm{ab}}$ & ND & $5^{\text {bcd }}$ & 5.74 & 0.004 \\
\hline 47 & Ethanol & ND & ND & $16^{\mathrm{b}}$ & ND & $1^{\mathrm{c}}$ & $11^{\mathrm{bc}}$ & ND & $31^{\mathrm{a}}$ & ND & $2^{\mathrm{c}}$ & $30^{\mathrm{a}}$ & 11.68 & 0.000 \\
\hline 55 & Alkenyl (fr) & $43^{\mathrm{b}}$ & $17^{\mathrm{b}}$ & $22^{\mathrm{b}}$ & $23^{\mathrm{b}}$ & $33^{\mathrm{b}}$ & $74^{\mathrm{a}}$ & $24^{\mathrm{b}}$ & $42^{\mathrm{b}}$ & $24^{\mathrm{b}}$ & $23^{\mathrm{b}}$ & $19^{b}$ & 5.04 & 0.007 \\
\hline 59 & Acetone; propanal & $1977^{\mathrm{bc}}$ & $870^{\mathrm{fg}}$ & $1137^{\text {ef }}$ & $2815^{\mathrm{a}}$ & $2033^{\mathrm{bc}}$ & $1719^{\text {cd }}$ & $2251^{\mathrm{b}}$ & $1395^{\mathrm{de}}$ & $2261^{b}$ & $602^{\mathrm{g}}$ & $2131^{\mathrm{bc}}$ & 27.63 & 0.000 \\
\hline 61 & Acetic acid & ND & $12^{\mathrm{c}}$ & $9^{\mathrm{cb}}$ & $1^{\mathrm{c}}$ & $21^{\mathrm{c}}$ & $215^{\mathrm{a}}$ & $2^{\mathrm{c}}$ & $74^{\mathrm{b}}$ & $2^{\mathrm{c}}$ & $18^{\mathrm{c}}$ & $20^{c}$ & 43.31 & 0.000 \\
\hline 63 & Dimethyl sulfide & $9^{c}$ & $4^{\mathrm{c}}$ & $153^{\mathrm{b}}$ & $4^{\mathrm{c}}$ & $5^{c}$ & ND & $8^{c}$ & $7^{\mathrm{c}}$ & $3^{\mathrm{c}}$ & $19^{c}$ & $260^{\mathrm{a}}$ & 13.93 & 0.000 \\
\hline 71 & Alkane (fr) & $7^{\text {cd }}$ & $106^{\mathrm{a}}$ & $19^{\text {bed }}$ & $2^{\mathrm{d}}$ & $30^{\mathrm{bcd}}$ & $3^{\mathrm{d}}$ & $33^{b}$ & $33^{\mathrm{bc}}$ & $38^{\mathrm{b}}$ & $9^{\text {cd }}$ & $2^{\mathrm{d}}$ & 13.10 & 0.000 \\
\hline 73 & 2-butanone; butanal & $52^{\mathrm{bcd}}$ & $34^{\text {de }}$ & $39^{\text {cde }}$ & $31^{\mathrm{e}}$ & $63^{\mathrm{b}}$ & $43^{\text {cde }}$ & $77^{\mathrm{ab}}$ & $56^{\mathrm{bc}}$ & $71^{\mathrm{ab}}$ & $9^{\text {f }}$ & $84^{\mathrm{a}}$ & 14.52 & 0.000 \\
\hline 75 & Propionic acid & $166^{\mathrm{a}}$ & $44^{\mathrm{e}}$ & $73^{\text {de }}$ & $93^{\mathrm{cd}}$ & $123^{\mathrm{bc}}$ & $82^{\text {cde }}$ & $97^{\mathrm{cd}}$ & $137^{\mathrm{ab}}$ & $91^{\mathrm{cd}}$ & $72^{\text {de }}$ & $140^{\mathrm{ab}}$ & 8.147 & 0.001 \\
\hline 83 & Butadiene; 3-methyl furan & $18^{\mathrm{a}}$ & ND & ND & ND & $3^{b}$ & $12^{\mathrm{a}}$ & $2^{\mathrm{b}}$ & $13^{\mathrm{a}}$ & $2^{b}$ & ND & $1^{b}$ & 5.470 & 0.005 \\
\hline 87 & $\begin{array}{l}\text { Diacetyl; 2-/3- methyl butanal; } \\
\text { pentanal }\end{array}$ & $6^{\mathrm{d}}$ & $154^{\mathrm{a}}$ & $26^{\mathrm{cd}}$ & ND & $41^{\mathrm{c}}$ & ND & $46^{\mathrm{c}}$ & $84^{\mathrm{b}}$ & $46^{\mathrm{c}}$ & $11^{\mathrm{d}}$ & $12^{\mathrm{d}}$ & 36.76 & 0.000 \\
\hline 89 & $\begin{array}{l}\text { Butanoic acid; isobutyric acid; } \\
\text { acetoin }\end{array}$ & $3^{\mathrm{cd}}$ & $57^{\mathrm{a}}$ & $5^{\mathrm{cd}}$ & ND & $28^{\mathrm{b}}$ & $11^{\mathrm{c}}$ & $28^{\mathrm{b}}$ & $21^{\mathrm{b}}$ & $23^{\mathrm{b}}$ & $8^{\mathrm{cd}}$ & $2^{\text {cd }}$ & 41.44 & 0.000 \\
\hline 97 & 2 -furfural & $185^{\mathrm{a}}$ & $2^{\mathrm{d}}$ & ND & ND & ND & $91^{\mathrm{b}}$ & $1^{\mathrm{d}}$ & $1^{\mathrm{d}}$ & $16^{\mathrm{c}}$ & $8^{\mathrm{cd}}$ & $2^{\mathrm{d}}$ & 422.44 & 0.000 \\
\hline 104 & NA & ND & ND & ND & $1^{\mathrm{b}}$ & $1^{\mathrm{b}}$ & ND & $18^{\mathrm{a}}$ & ND & $3^{\mathrm{a}}$ & $1^{\mathrm{b}}$ & ND & 5.25 & 0.006 \\
\hline 107 & 2 ethyl pyrazine; hexanoic acid & $3^{b}$ & $1^{\mathrm{b}}$ & ND & $1^{\mathrm{b}}$ & $21^{\mathrm{a}}$ & ND & $\mathrm{ND}$ & $1^{b}$ & ND & $1^{\mathrm{b}}$ & $1^{\mathrm{b}}$ & 9.58 & 0.000 \\
\hline 115 & Heptanone; heptanal & $20^{\mathrm{a}}$ & $3^{\mathrm{b}}$ & $8^{\mathrm{b}}$ & $1^{b}$ & $3^{\mathrm{b}}$ & ND & $28^{\mathrm{a}}$ & $2^{\mathrm{b}}$ & $28^{\mathrm{a}}$ & $2^{\mathrm{b}}$ & $1^{b}$ & 8.99 & 0.001 \\
\hline 116 & Hexanoic acid; caproic acid & $1^{\mathrm{b}}$ & ND & $2^{\mathrm{ab}}$ & ND & ND & ND & $15^{\mathrm{a}}$ & $2^{\mathrm{ab}}$ & $17^{\mathrm{a}}$ & ND & $1^{\mathrm{b}}$ & 3.18 & 0.035 \\
\hline 126 & NA & ND & ND & ND & ND & ND & ND & ND & ND & ND & $18^{\mathrm{a}}$ & ND & 9.00 & 0.001 \\
\hline 143 & Nonanone; nonanal & $6^{\mathrm{ab}}$ & ND & $14^{\mathrm{a}}$ & $1^{\mathrm{bc}}$ & ND & ND & $6^{\mathrm{ab}}$ & $1^{\mathrm{bc}}$ & $6^{\mathrm{ab}}$ & $1^{\mathrm{bc}}$ & $1^{\mathrm{bc}}$ & 3.04 & 0.041 \\
\hline
\end{tabular}

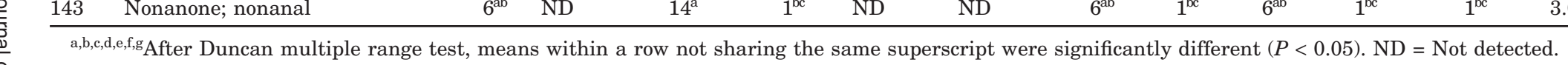

${ }^{1}$ Whey samples: ACASI = acid casein; CHEDA = Cheddar, company A; CHEDB = Cheddar, company B; CHEDP = Cheddar, pilot plant; GOUDA = Gouda cheese; LACAS = lactic acid casein; MOZZ = Mozzarella cheese; PAN = Paneer cheese; QUARG = Quarg cheese; RCASA = rennet casein, company A; RCASP = rennet casein, pilot plant.

$2 \mathrm{~m} / z=$ Mass to charge ratio.

${ }^{3}$ Tentative identification; $(\mathrm{fr})=$ fragment, $(\mathrm{r})=$ radical, $\mathrm{NA}=$ Not attributed 


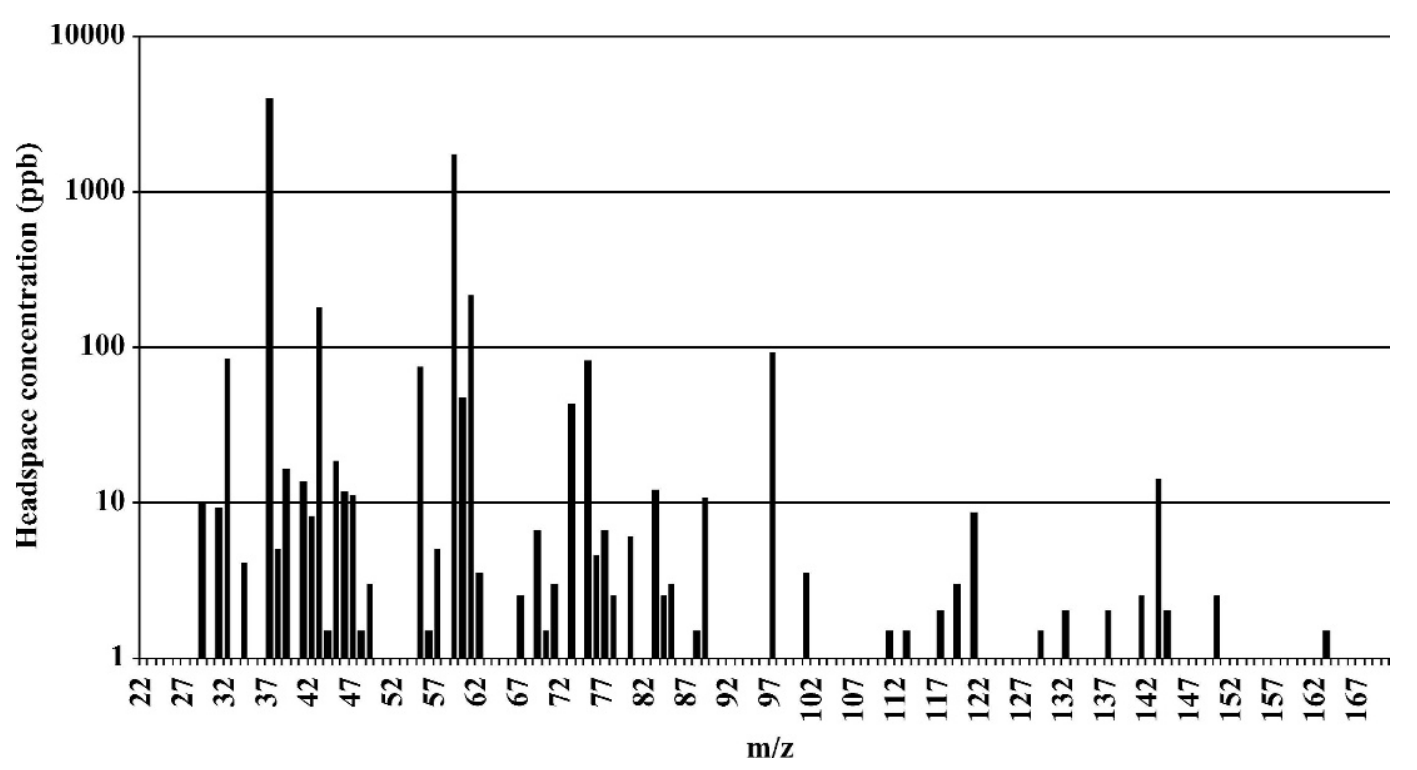

Figure 2. Proton transfer reaction-mass spectrometry headspace profile of lactic acid casein whey sample.

2003; Mahajan et al., 2004), and fresh whey (Carunchia Whetstine et al., 2003). Knowledge of fractionation patterns, and isomeric and isobaric compounds in using the PTR-MS technique (Buhr et al., 2002) was also considered.

\section{PCA of Volatile Compound Data}

The ANOVA of PC scores of the volatile compound data, based on duplicate measurements (as for the sensory data), indicated that the first 9 PC significantly discriminated $(P<0.05)$ between samples (ANOVA not shown). This finding demonstrated that PTR-MS is a technique capable of analyzing a remarkable sample complexity that can be reproducibly measured.

The PCA diagram in Figure 4 showed that the first PC was a function of volatile compounds that develop during fermentation in milk-based products (Reineccius, 1994), that is, acetaldehyde, 2,3 butadione (diacetyl), and 2 butanol-3-one (acetoin). Quarg and Mozzarella were positioned close to each other on the PCA diagram of PC 1 against PC 2 consistent with their sensory evaluation results (for odor). This PCA diagram explained $43 \%$ of the total variance and was based on

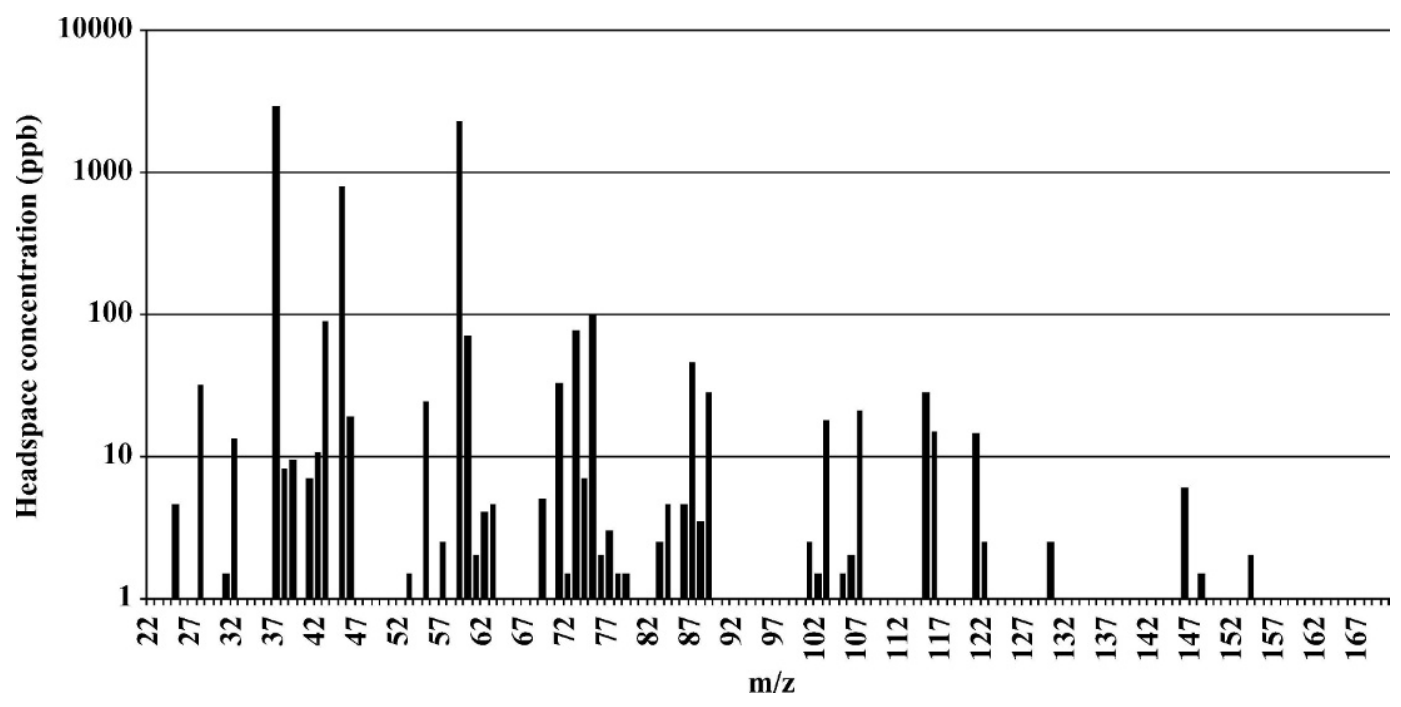

Figure 3. Proton transfer reaction-mass spectrometry headspace profile of Mozzarella whey sample. 


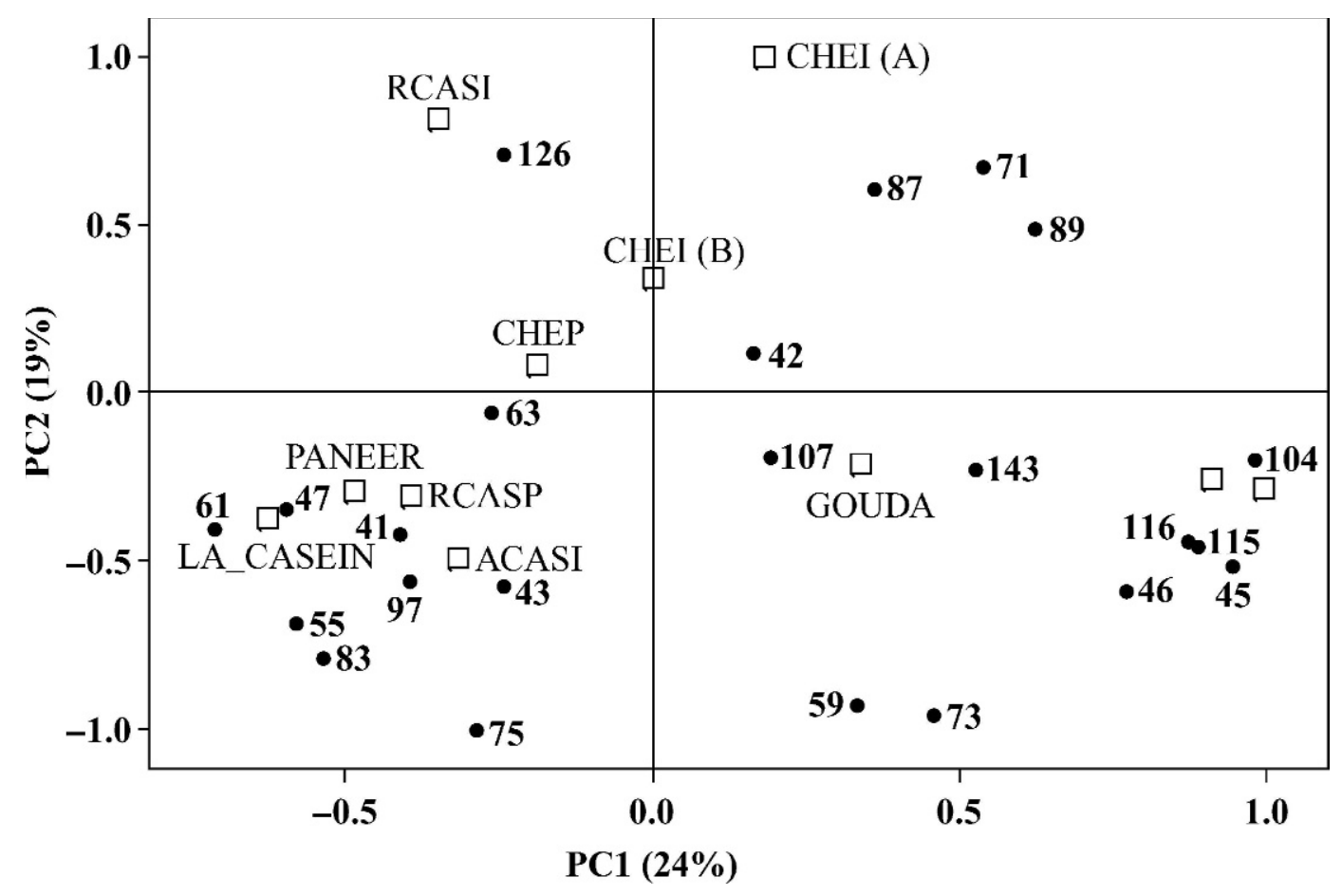

Figure 4. Results of principal component analysis of volatile compounds (numbers refer to $\mathrm{m} / z$ ) detected by proton transfer reactionmass spectrometry showing the first 2 principal components (PC1 and PC2). Whey samples: ACASI = acid casein; CHEI(A) = Cheddar, company A; CHEI $(\mathrm{B})=$ Cheddar, company B; CHEP = Cheddar, pilot plant; GOUDA = Gouda cheese; LA_CASEIN = lactic acid casein; MOZZ = Mozzarella cheese; PANEER = Paneer cheese; $\mathrm{QUARG}=$ Quarg cheese RCASI = rennet casein, company $\mathrm{A} ; \mathrm{RCASP}=$ rennet casein, pilot plant.

significant masses only. Principal component 2 was mainly a function of volatile compounds such as 2-butanone $(\mathrm{m} / \mathrm{z} 73)$, propionic acid $(\mathrm{m} / \mathrm{z} 75)$, and butadiene $(\mathrm{m} / \mathrm{z} 83)$; and PC 3 was essentially a function of propan1-ol (m/z 43), an alkane fragment (m/z 71), diacetyl $(\mathrm{m} / \mathrm{z}$ $87)$, and nonanone ( $\mathrm{m} / \mathrm{z} 143)$. The $9 \mathrm{PC}$ that significantly discriminated $(P<0.05)$ between samples accounted for $98 \%$ (cumulative sum) of the total variance.

\section{PLSR of Volatile Compound and Sensory Data}

Partial least squares regression Type 2 (multiresponse) of chemical and sensory data fitted well the sensory and chemical data of this study (calibration correlation coefficient was $>0.7$ for most characteristics); however, using this procedure, no PC was validated, possibly due to complex interrelationships between chemical compounds or high multiple collinearity of sensory attributes.

Partial least squares regression Type 1 (single response) was then applied as an alternative. Using this procedure, relationships between volatile compounds and sensory attributes were determined, one attribute at a time, and several successful regression models were developed (Table 5). Attributes for which regression models with moderate to high validation coefficients ranging 0.40 to 0.94 were developed included "rancid" and "natural yogurt" odor and, to a lesser extent, "cheesy" and "dirty" odor, and "caramelized milk," "sweet," and "oaty" flavors.

"Rancid" odor could be determined by the presence of $\mathrm{m} / \mathrm{z} 83$ (attributed to butadiene or to 3-methyl furan) and 97 (not attributed), and the absence of $\mathrm{m} / \mathrm{z} 42$ (attributed to an allyl radical or to dimethylamine) and $\mathrm{m} / \mathrm{z} 47$ (attributed to ethanol). The regression model for "natural yogurt" odor also had a reasonable predictive ability based upon the presence of $\mathrm{m} / \mathrm{z} 45$ (attributed to acetaldehyde), 46 (attributed to a hydrocarboxyl radical), 87 (attributed to diacetyl), 104 (not attributed), 115 (attributed to heptanone), and 116 (attributed to hexanoic acid).

Most of the volatiles detected in this study have been reported to have flavor significance in dairy products but only some coincide with descriptive or associative terms (Bodyfelt et al., 1988). To our knowledge, there are no studies on flavor of acid whey obtained from mineral acid casein whey production, to which the results obtained could be compared. However, the deter- 
Table 5. Results of partial least squares regression analysis, indicating positive and negative correlations between volatile compounds and specific sensory attributes. Integers refer to mass to charge ratio. Best fit calibration coefficients (measured) and validation coefficients (predictive ability) of models are included.

\begin{tabular}{lccll}
\hline Attribute $^{1}$ & $\begin{array}{l}\text { Positive } \\
\text { correlation }\end{array}$ & $\begin{array}{l}\text { Negative } \\
\text { correlation }\end{array}$ & Calibration & Validation \\
\hline (o)-Milky & 42,107 & 55,83 & 0.70 & 0.40 \\
(o)-Rancid & 83,97 & 42,47 & 0.96 & 0.94 \\
(o)-Cheesy & 143 & 104 & 0.86 & 0.63 \\
(o)-Dirty & 55,83 & 47,115 & 0.78 & 0.45 \\
(f)-Caramelized milk & 42,126 & $59,73,83$ & 0.75 & 0.60 \\
(f)-Natural yogurt & $45,46,87,104,115116$ & & 0.78 & 0.65 \\
(f)-Sweet & 126 & $45,59,61,73$ & 0.76 & 0.60 \\
(f)-Oaty & 87,126 & 59,73 & 0.75 & 0.60 \\
\hline
\end{tabular}

${ }^{1}(\mathrm{o})=$ Odor; (f) $=$ flavor.

mination of moderate validation coefficients may help to understand the importance of the proportions and even absence of volatile compounds to elicit particular sensory characteristics such as "dirty" odor, which characterized acid casein wheys, and "oaty" odor and flavor, which characterized rennet casein wheys in this study.

\section{CONCLUSIONS}

Cheddar, Gouda, and rennet wheys ("sweet" cheese and rennet wheys), as raw materials, provided a bland, "sweet"/"milky" flavor base, adequate for producing liquid dairy beverages. Differentiation of flavor of whey based on the activity of the starter cultures used for cheese making at the time of whey drainage was limited to the extent in which a nonspecific "cheesy" aroma (as for unripe cheese) was perceived in cheese whey (Gouda and Cheddar) samples.

Results suggested that starter cultures might influence flavor of whey to different degrees, acquiring a more specific cheese-like character relative to the variety from which it originated, only if fermentation progresses to low $\mathrm{pH}$ values before drainage of whey. Precise control of the temperature of whey or inactivation of starter cultures, particularly fast-acidification or fastfermenting commercial strains, is therefore important. For other types of products to be made from whey, a cheese-like flavor could be advantageous.

The absence of a starter culture in the process of obtaining rennet whey (both industrial and pilot-plant scale) led to a sweet-tasting product with a subtle odor suitable as a neutral base for production of dairytype beverages.

On the other hand, off-flavors such as "bitter," "stale," "rancid," and "chemical" perceived in acid casein whey samples may be caused by reactions induced by the acid added during the manufacture of the casein.

The use of PTR-MS provided a reliable volatile fingerprint of each sample, useful for quality control purposes, as it efficiently provided chemical information related to the sensory quality of the raw material. Application of PTR-MS is also capable of guiding a more effective and efficient product development through the potential for generation of a desired sensory profile starting from adequate sensory characteristics in the raw material.

\section{ACKNOWLEDGMENTS}

F. J. Gallardo-Escamilla gratefully acknowledges funding from Consejo Nacional de Ciencia y Tecnología (CONACyT), Mexico, and postgraduate leave from Universidad Autónoma Metropolitana, Mexico.

\section{REFERENCES}

Badings, H. T. 1991. Milk. Pages 91-106 in Volatile compounds in foods and beverages. H. Maarse, ed. Marcel Dekker, Inc., New York, NY.

Bodyfelt, F. W., J. Tobias, and G. M. Trout. 1988. The sensory evaluation of dairy products. AVI Van Nostrand Reinhold, New York, NY.

Boscaini, F., S. van Ruth, F. Basioli, F. Gasperi, and T. D. Märk. 2003. Gas chromatography olfactometry (GC-O) and proton transfer reaction mass spectrometry (PTR-MS) analysis of the flavor profile of Grana Padano, Parmigiano Reggiano, and Grana Trentino cheeses. J. Agric. Food Chem. 51:1782-1790.

Buhr, K., S. van Ruth, and C. Delahunty. 2002. Analysis of volatile flavor compounds by PTR-MS: Fragmentation patterns and discrimination between isobaric and isomeric compounds. Int. J. Mass Spectrom. 221:1-7.

Carunchia Whetstine, M. E., J. D. Parker, M. A. Drake, and D. K. Larick. 2003. Determining flavor and flavor variability in commercially produced liquid Cheddar whey. J. Dairy Sci. 86:439448.

Coolbear, T., V. L. Crow, R. Holland, S. Q. Liu, and J. R. Reid. 2003. Lactococcus spp., Flavor development. Pages $1520-1525$ in Encyclopedia of Dairy Sciences. H. Roginski, J. Fuquay, and P.F. Fox, ed. Academic Press, London, UK.

Durham, R. J., J. A. Hourigan, R. W. Sleigh, and R. L. Johnson. 1997. Whey fractionation: Wheying up the consequences. Food Australia 49:460-465.

Friedrich, J. E., and T. E. Acree. 1998. Gas chromatography olfactometry $(\mathrm{GC} / \mathrm{O})$ of dairy products. Int. Dairy J. 8:235-241.

Hansel, A., A. Jordan, R. Holzinger, P. Prazeller, W. Vogel, and W. Lindinger. 1995. Proton transfer reaction mass spectrometry: Online trace gas analysis at the ppb level. Int. J. Mass Spectrom. Ion Process. 149/150:609-619. 
ISO. 1988. Sensory Analysis. ISO 8589: General guidance for the design of test rooms. International Organization for Standardization. Paris, France.

ISO. 1993. Sensory Analysis. ISO 8586: General guidance for the selection, training and monitoring of assessors. International Organization for Standardization. Geneva, Switzerland.

Jelen, P. 1992. Whey cheeses and beverages. Pages 157-193 in Whey and lactose processing. J. G. Zadow, ed. Elsevier Applied Science, New York, NY

Jensen, R. G., and M. Kroger. 2000. The importance of milk and milk products in the diet. Pages 51-52 in Handbook of Dairy Foods and Nutrition. 2nd ed. G. D. Miller, J. K. Jarvis, and L. D. McBean, ed. CRC Press LLC, Boca Raton, FL.

Ji, T., and Z. U. Haque. 2003. Cheddar whey processing and source: 1. Effect on composition and functional properties of whey protein concentrates. Int. J. Food Sci. Technol. 38:453-461.

Johansen, A. G., G. E. Vegarud, and S. Skeie. 2002. Seasonal and regional variation in the composition of whey from Norwegian Cheddar-type and Dutch-type cheeses. Int. Dairy J. 12:621-629.

Karagul-Yuceer, Y., M. A. Drake, and K. R. Cadwallader. 2003. Aroma-active components of liquid Cheddar whey. J. Food Sci. 68:1215-1219.

Kosikowski, F. V., and V. V. Mistry. 1997. Whey and whey foods. Pages 422-453 in Cheese and Fermented Milk Foods. Vol. I. F. V. Kosikowski, LLC, Great Falls, VA.

Laye, I., D. Karleskind, and C. V. Morr. 1995. Chemical and volatile organic compounds composition of whey protein concentrate. Pages 769-784 in Food Flavors: Generation, Analysis and Process Influence. G. Charalambous, ed. Elsevier Science Publ., Amsterdam, The Netherlands.

Lindinger, W., A. Hansel, and A. Jordan. 1998. On-line monitoring of volatile organic compounds at pptv levels by means of protontransfer-reaction mass spectrometry. Medical applications, food control and environmental research. Int. J. Mass Spectrom. Ion Process. 173:191-241.

Liu, S. Q., and R. Holland. 2003. Leuconostoc spp. Pages 1539-1543 in Encyclopedia of Dairy Sciences. H. Roginski, J. Fuquay, and P. F. Fox, ed. Academic Press, London, UK.

Livney, Y. D., and R. L. Bradley. 1994. Factors affecting flavor of whey as an ingredient in ice cream and other frozen desserts. Cultured Dairy Products J. November:23-27.

MacFie, H. J., N. Bratchel, K. Greenhoff, and I. V. Vallis. 1989. Designs to balance the effect of order of presentation and firstorder carry-over effects in hall tests. J. Sens. Stud. 4:129-148.

Mahajan, S. S., L. Goddik, and C. M. Qian. 2004. Aroma compounds in sweet whey powder. J. Dairy Sci. 87:4057-4063.

Martens, M., and H. Martens. 1986. Partial least squares regression. Pages 293-359 in Statistical Procedures in Food Research. J. R. Piggott, ed. Elsevier Applied Science, London, UK.
Mayr, D., R. Margesin, F. Schinner, and T. D. Märk. 2003. Detection of the spoiling of meat using PTR-MS. Int. J. Mass Spectrom. 223/224:229-235.

McDonnell, E., S. Hulin-Bertaud, E. M. Sheehan, and C. M. Delahunty. 2001. Development and learning process of a sensory vocabulary for the odor evaluation of selected distilled beverages using descriptive analysis. J. Sens. Stud. 16:425-445.

McGugan, W. A., E. Larmond, and D. B. Emmons. 1979. Some observations on the flavor of acid whey. J. Inst. Can. Sci. Technol. Aliment. 12:32-35.

Mehrens, H.-A. 2004. Whey: A valuable ingredient. Food Technol. Int. 2004. Sterling Publ. Ltd., London, UK.

Mills, O. E. 1993. Flavor of whey protein concentrate. Pages 139-149 in Food: Flavors, Ingredients and Composition. G. Charalambous, ed. Elsevier Science Publ., New York, NY.

Morr, C. V., and Y. W. Ha. 1991. Off flavors of whey protein concentrates: A literature review. Int. Dairy J. 1:1-11.

Olling, C. C. J., and F. J. P. van Luin. 1988. Composition of cheese whey in Friesland. Neth. Milk Dairy J. 42:488-489.

Pollien, P., C. Lindinger, C. Yeretzian, and I. Blank. 2003. Proton transfer reaction mass spectrometry, a tool for on-line monitoring of acrylamide formation in the headspace of Maillard reaction systems and processed food. Anal. Chem. 75:5488-5494.

Rankin, S. A. 2003. Factors affecting variation of commercial sweet whey powder flavor. Pages 52-54 in Proc. IFT Annu. Meeting, Chicago, IL. IFT, Chicago, IL.

Reineccius, G. 1994. Flavor of dairy products. Pages 88-93 in Source book of flavors. Chapman \& Hall, New York, NY.

Romero, D. A. 1992. Bacteria as potential sources of flavor metabolites. Food Technol. November:122-126.

Ryder, D. N. 1980. Economic considerations of whey processing. J. Soc. Dairy Technol. 33:73-77.

Tamime, A. Y., and R. K. Robinson. 1999. Yoghurt Science and Technology. 2nd ed. Woodhead Publishing Ltd., Cambridge, UK.

Tomaino, R. M., L. G. Turner, and D. K. Larick. 2004. The effect of Lactococcus lactis starter cultures on the oxidative stability of liquid whey. J. Dairy Sci. 87:300-307.

Urbach, G. 1995. Contribution of lactic acid bacteria to flavor compound formation in dairy products. Int. Dairy J. 5:877-903.

Ward, L. J. H., G. P. Davey, H. A. Heap, and W. J. Kelly. 2003. Lactococcus spp.: Lactococcus lactis. Pages 1511-1516 in Encyclopedia of Dairy Sciences. H. Roginski, J. Fuquay, and P. F. Fox, ed. Academic Press, London, UK.

Zadow, J. G. 2003. Whey and whey powders: Production and uses. Pages 6147-6152 in Encyclopedia of Food Science and Nutrition. 2nd ed. B. Caballero, L. Trugo, and P. Finglas, ed. Academic Press, Oxford, UK. 